\section{US-Cuba row over insects goes to weapons meeting}

[PARIS] The countries that have signed the 1975 Biological Weapons Convention will meet next week in Geneva to hear Cuban allegations that last year the United States discharged the insect pest Thrips palmi over Cuba to damage the country's agriculture. The US State Department dismisses the allegations as "outrageous".

The meeting, requested by Russia on behalf of Cuba, will be the first time that the parties to the convention have heard allegations of an infraction of the convention.

But the meeting has no powers to make further investigations or impose sanctions, because the convention lacks a legally binding verification regime, unlike the Nuclear Non-Proliferation Treaty and the Chemical Weapons Convention. Efforts to add such a regime to the treaty have only recently started (see Nature 388, 317; 1997).

At most, the meeting could recommend that the United Nations Security Council request an investigation of the allegations, although neither the United States nor Cuba would have any obligation to comply. One official from the US State Department says, however, that the United States would comply. It is "confident of its case", and wants to act in the spirit of the treaty.

The controversy provides a clear example of why a verification regime is badly needed, says Alistair Hay, a chemical pathologist at the University of Leeds in the United Kingdom, and an expert on chemical and biological weapons. Such a regime could have allowed an international inspection team to be sent to Cuba at short notice.

Use of biological weapons is "very difficult" to prove at the best of times, says Hay, because their effects may be indistinguishable from natural outbreaks of disease. Adding to the uncertainty is the difficulty of verifying claims so long after the alleged incident, which is said to have occurred on 21 October 1996.

Cuba alleges that on this day a State Department aircraft designed to eradicate narcotics crops, which had been authorized to fly across Cuban airspace to Colombia, sprayed a substance over an area known as the Girón corridor, where a Thrips palmi epidemic broke out a few weeks later. The aircraft had been seen releasing an unidentified substance by the pilot of a civilian Cuban airliner flying 300 metres below it (see map).

The State Department says that the pilot had released only smoke to signal its presence to the Cuban aircraft, and was following "safe and prudent" aviation procedures. Cuba argues that the Cuban pilot knew the difference between smoke and a substance. It contests that the US pilot needed to signal its presence, arguing that the flight plan gave responsibility for aircraft separation to air traffic control. Cuba questions the US assertion that all its narcotics control aircraft are fitted with smoke generators.

Hay points out that Cuba's case relies heavily on circumstantial evidence. Its position may be further weakened, he says, by the fact that Thripspalmi has spread throughout the Caribbean since it first appeared there in 1985, and is now found in Jamaica, the Dominican Republic and Haiti.

But Dorothy B. Preslar, of the Federation of American Scientists' programme on chemical and biological weapons, says that the insect would have been expected to have appeared on the east of the island and not in the west as in fact occurred, given the geography and prevailing weather. But she says that this could be accounted for by scenarios other than deliberate infestation.

Many observers are sceptical that the United States would take the political risk of using biological weapons, because it has been a leading proponent of efforts to reinforce the Biological Weapons Convention with a verification regime.

Yonah Alexander, director of the terrorism studies programme at George Washington University in Washington, DC, dismisses the Cuban accusation as "propaganda" intended to put the United States in a "nowin situation". Whatever the United States says, doubt will be cast on its credibility, Alexander says.

Others argue, however, that the United States's record of covert operations in Cuba leaves room for speculation.

Declan Butler

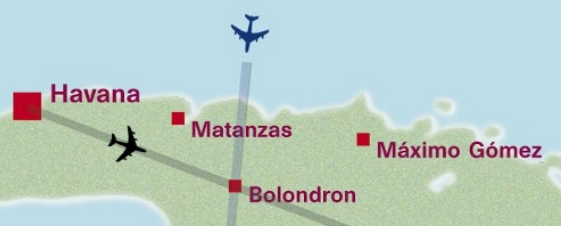

\section{Royal observatory could return to Greenwich site}

[LONDON] Britain's Royal Greenwich Observatory (RGO) may - at least in spirit - be returning to the Thames-side site on which it was established more than 300 years ago, following the government's decision to close its current site in Cambridge and merge its research-related activities with those of the Royal Observatory in Edinburgh (see Nature 388, 105-106; 1997).

The observatory's present managers are drawing up a business plan under which the RGO's expertise in telescope design and technical support would be retained in a single non-profit organization. This would remain at Cambridge, and offer a telescope design consultancy service with Liverpool John Moores University, which provides telescope-manufacturing facilities.

The two institutions are already involved in designing and manufacturing a 2-metre telescope for India, and are keen to extend their collaboration on a commercial scale.

At the same time, the National Maritime Museum, which runs the museum on the site of the original observatory in Greenwich in southeast London, is keen to use the name to boost its highly regarded public education programme in the history of astronomy. The old observatory receives 400,000 visitors a year, and many astronomy enquiries from members of the public, who still think that Greenwich houses an active observatory.

Paul Murdin, head of astronomy at the Particle Physics and Astronomy Research Council (PPARC) and a member of the board of trustees of the maritime museum, says the two proposals could be linked under a single umbrella, with the RGO's scientific and technical expertise remaining in Cambridge, and the expanded public education activities run from Greenwich.

Jasper Wall, the RGO's director, says he is not against such an idea, but would want to ensure that a prominent link with the maritime museum does not overshadow the RGO's research. "The RGO is not a museum, and has never been one," he says.

One project being considered by the maritime museum is the building of a 2-metre telescope in Hawaii. This could be used via satellite by computer terminals in schools in the United Kingdom, or in the Greenwich museum. The 12-hour time difference would mean that the Hawaiian night sky could be seen in daylight hours in Britain.

PPARC is at present responsible for managing both royal observatories. Ken Pounds, professor of astronomy at the University of Leicester and PPARC's chief executive, says that a decision will be made next year.

EhsanMasood 